\title{
Nowe czynniki prognostyczne w pierwotnym włóknieniu szpiku - aktualny stan wiedzy
}

\author{
New prognostic factors in primary myelofibrosis \\ - a current state of knowledge
}

\author{
Marta A. Sobas, Tomasz Wróbel \\ Klinika Hematologii, Nowotworów Krwi i Transplantacji Szpiku, Uniwersytet Medyczny we Wrocławiu
}

\begin{abstract}
Streszczenie
Pierwotne wtóknienie szpiku (PMF) to najgorzej rokujacy wariant nowotworów mieloproliferacyjnych Filadelfia-ujemnych. Obecnie jedyna dostepna terapia, dajaca szanse uzyskania petnego wyleczenia, jest przeszczepienie allogenicznych krwiotwórczych komórek macierzystych (allo-HSCT). Jednak procedura ta, ze wzgledu na duza liczbe powiktań, jest zarezerwowana tylko dla chorych o przewidywanym krótkim czasie przeżycia. Lepsze poznanie patogenezy PMF umożliwito stworzenie nowych leków, między innymi inhibitora JAK2 - ruksolitynibu. Jednocześnie zaobserwowano, ze nowo odkryte zaburzenia genetyczne sq niezaleznymi czynnikami prognostycznymi w PMF. W ostatnich latach powstało kilka nowych propozycji wskaźników prognostycznych, które wymagaja dalszej weryfikacji w celu lepszego zdefiniowaniu grup ryzyka dla chorych na PMF. Podstawowe pytanie w erze nowych leków na PMF dotyczy tego, u jakich pacjentów i kiedy należy przeprowadzić allo-HSCT.
\end{abstract}

Słowa kluczowe: pierwotne włóknienie szpiku, mutacje sprawcze, mutacje wysokiego ryzyka, czynniki prognostyczne

Hematologia 2017; 8, 4: 271-279

\begin{abstract}
Out of all Philadelphia-negative myeloproliferative neoplasms, primary myelofibrosis has the worst prognosis. Currently, an allogeneic hematopoietic stem cell transplantation (allo-HSCT) is currently the only curative method for patients with primary myelofibrosis. This procedure however bears a high risk of complications and is reserved for only those patients with short overall survival. The development of new drugs (ruxolitynib amongst others) was made possible thanks to an improved understanding of the pathogenesis of primary myelofibrosis. It was also observed that newly discovered genetical abnormalities constituted independent risk factors in patient with primary myelofibrosis. Furthermore, a few new proposals of risk prognostic scores have been developed. These risk scores are still not a gold standard and new studies are required to verify their use whenever risk groups have been better defined in primary myelofibrosis patients. In the new drug era, the main question is which patients should now receive allo-HSCT.
\end{abstract}

Key words: primary myelofibrosis, driver mutation, high risk mutation, risk factors

Hematologia 2017; 8, 4: 271-279

Adres do korespondencji: Marta Sobas, Klinika Hematologii, Nowotworów Krwi i Transplantacji Szpiku, Uniwersytet Medyczny we Wrocławiu, ul. Pasteura 4, 50-367 Wrocław, tel. +48 71784 25 99, faks +48 717840112 ,

e-mail: marta.sobas@gmail.com 


\section{Wprowadzenie}

Nowotwory mieloproliferacyjne Filadelfia-ujemne (MPN Ph-, myeloproliferative neoplasm Philadelphia-negative) to choroby klonalne, w których dochodzi do niekontrolowanej proliferacji macierzystych komórek krwiotwórczych szpiku [1]. Zgodnie $z$ obowiązującymi kryteriami diagnostycznymi, według klasyfikacji Światowej Organizacji Zdrowia (WHO, World Health Organization) z 2016 roku, do MPN Ph(-) zalicza się cztery jednostki - czerwienicę prawdziwą (PV, polycythemia vera), nadpłytkowość samoistną (ET, essential thrombocythemia), pierwotne włóknienie szpiku (PMF, primary myelofibrosis) oraz dodatkowo wyszczególnioną prefibrotyczną fazę PMF (prePMF, prefibrotic primary myelofibrosis), która często mylnie jest diagnozowana jako ET [1, 2]. Zawsze jednak należy podejrzewać prePMF u chorych na nadpłytkowość oraz z podwyższoną aktywnością dehydrogenazy mleczanowej (LDH, lactate dehydrogenase), niedokrwistością, podwyższoną leukocytozą i splenomegalią [2, 3]. Diagnostyka różnicowa tych dwóch jednostek jest możliwa dzięki trepanobiopsji. Odróżnienie ET od prePMF jest bardzo ważne ze względu na istotnie różne rokowanie (znacznie gorsze w grupie prePMF). Kvasnicka i wsp. [4] sugerują, że ET jest raczej chorobą łagodną, cechującą się bardzo niskim ryzykiem transformacji do mielofibrozy/ostrej białaczki. Istnieje podejrzenie, że większość chorych na nadpłytkowość, u których doszło do transformacji do mielofibrozy, wstępnie jest mylnie diagnozowanych jako chorujących na ET zamiast na prePMF [4]. Problem ten wydaje się szczególnie ważny w aspekcie pojawiających się nowych czynników prognostycznych oraz nowych leków.

Rokowanie w przypadku PMF jest szczególnie niekorzystne. Medianę przeżycia u tych chorych ocenia się jako między 2 a 10 lat [5]. Najczęstszymi przyczynami zgonu są transformacja do ostrej białaczki szpikowej (AML, acute myeloid leukemia) występująca u $31 \%$, objawy wynikające $z$ progresji włóknienia (m.in. pogorszenie stanu ogólnego, niedokrwistość, skaza krwotoczna związana $z$ małopłytkowością, hepatosplenomegalia $z$ wtórnym nadciśnieniem wrotnym $z$ wodobrzuszem i żylakami przełyku) u $18 \%$ pacjentów oraz zakrzepica i powikłania sercowo-naczyniowe u 13\% chorych [5].

\section{Obecne wskaźniki prognostyczne}

Pierwsza skalę rokowniczą w PMF (skalę Lille) zaproponowali w 1996 roku Dupriez i wsp. [6].
Czynniki prognostyczne ustalano przy rozpoznaniu i obejmowały tylko dwie zmienne - stężenie hemoglobiny $(\mathrm{Hb})$ poniżej $10 \mathrm{~g} / \mathrm{dl}$ oraz liczbę leukocytów poniżej 4 lub powyżej $30 \times 10 \mathrm{G} /$ l. Chorzy byli klasyfikowani do trzech grup prognostycznych: niskiego ryzyka (0 czynników) z przewidywaną medianą przeżycia całkowitego (OS, overall survival) 93 miesięcy, pośredniego (1 czynnik) $z$ medianą OS 26 miesięcy i wysokiego (2 czynniki) $z$ medianą OS 19 miesięcy. Ograniczeniem tej skali były trudności $z$ rozróżnieniem chorych $z$ grup ryzyka pośredniego i wysokiego. Kolejną wprowadzoną skalą była IPSS (International Prognostic Scoring System) zaproponowana przez IWG-MRT (International Working Group for Myeloproliferative Neoplasms Research and Treatmant) w 2009 roku [7]. Obejmowała ona pięć czynników ryzyka: wiek powyżej 65 lat, stężenie Hb poniżej $10 \mathrm{~g} / \mathrm{dl}$, liczbę leukocytów powyżej $25 \mathrm{G} / 1$, obecność we krwi obwodowej więcej niż $1 \%$ blastów, obecność objawów systemowych. Na podstawie IPSS można wyróżnić cztery grupy chorych: grupę niskiego ryzyka (nieobciążoną czynnikami ryzyka) z medianą OS 11,3 roku, grupę ryzyka pośredniego-1 (jeden czynnik) $z$ medianą 7,9 roku, pośredniego-2 (dwa czynniki) $z$ medianą 4 lata, grupę wysokiego ryzyka $(\geq 3$ czynniki) $z$ medianą 2,3 roku. Podstawową wadą IPSS pozostaje fakt, że oceny dokonuje się tylko w chwili rozpoznania.

Modyfikacja IPSS to tak zwany dynamiczny IPSS, czyli DIPPS (Dynamic International Prognostic Scoring System) [8]. W tej skali ocenia się te same parametry, co w IPSS, jednak już w trakcie przebiegu choroby. Dodatkowo nadaje ona większe niekorzystne znaczenie prognostyczne niedokrwistości. Zgodnie $z$ liczbą przyznanych punktów chorych dzieli się na cztery grupy rokownicze: niskiego ryzyka ( 0 pkt.) - mediana OS nie została osiagnnięta, ryzyka pośredniego-1 (1 lub 2 pkt.) mediana OS 14,2 roku, ryzyka pośredniego-2 (3 lub 4 pkt.) - mediana OS 4 lata, wysokiego ryzyka (5 lub 6 pkt.) - mediana OS 1,5 roku.

Tam i wsp. [9] w 2009 roku oraz Hussein i wsp. [10] w 2010 roku zwrócili uwagę na znaczenie rokownicze zmian cytogenetycznych w PMF. Zgodnie $z$ publikacją Tam i wsp. do niekorzystnych czynników cytogenetycznych zalicza się alterację chromosomów 5, 7 i 17 oraz kariotyp złożony. Ponadto Hussein i wsp. zaobserwowali, że niekorzystne rokowniczo są złożony kariotyp i trisomia chromosomu 8 . Zmiany cytogenetyczne występują u około $30 \%$ chorych $z$ włóknieniem szpiku. Powyższe czynniki uwzględniono w kolejnej modyfikacji wskaźnika rokowniczego nazwanej DIPSS 
Tabela 1. Aktualne skale prognostyczne dotyczące mielofibrozy; A. Czynniki ryzyka; B. Grupy ryzyka i mediana przeżycia Table 1. Currently used prognostic risk scores in myelofibrosis; A. Prognostic risk factors; B. Risk groups

A. Czynniki ryzyka

\begin{tabular}{|l|c|c|c|}
\hline Czynnik ryzyka & \multicolumn{3}{|c|}{ Punktacja } \\
\hline Wiek > 65 lat & IPSS & DIPSS & DIPSS plus \\
\hline Objawy ogólne & 1 & 1 & 1 \\
\hline Hemoglobina < 10 g/dl & 1 & 2 & 1 \\
\hline Leukocyty > 25 G/l & 1 & 1 & 1 \\
\hline Odsetek blastów we krwi obwodowej $\geq 1 \%$ & 1 & 1 & 1 \\
\hline Zależność od przetoczeń kkcz* & 1 & - & 1 \\
\hline Niekorzystny kariotyp** & - & - & 1 \\
\hline Liczba płytek krwi < 100 G/l & - & - & 1 \\
\hline
\end{tabular}

*Niekorzystny kariotyp: kariotyp złożony, trisomia 8, monosomia 7/7q-, i(17q), inv(3), monosomia 5/5q-, 12p-, rearanżacja 11q23; kkcz - koncentrat krwinek czerwonych

\section{B. Grupy ryzyka i mediana przeżycia}

\begin{tabular}{|l|c|c|}
\hline Liczba punktów & Kategoria ryzyka & Mediana przeżycia (lata) \\
\hline IPSS & Niskie & 11,3 \\
\hline 0 & Pośrednie-1 & \multicolumn{1}{|c|}{2,9} \\
\hline 1 & Pośrednie-2 \\
\hline 2 & Wysokie & Nieosiągnięta \\
\hline$>3$ & & 14,2 \\
\hline DIPSS & Niskie & 4 \\
\hline 0 & Pośrednie-1 \\
\hline $1-2$ & Pośrednie-2 & 1,5 \\
\hline $3-4$ & Wysokie & 15,4 \\
\hline $5-6$ & & 6,5 \\
\hline DIPSS plus & Niskie & 2,9 \\
\hline 0 & Pośrednie-1 & 1,3 \\
\hline 1 & Pośrednie-2 & \\
\hline $2-3$ & Wysokie & \\
\hline$\geq 4$ & & \\
\hline
\end{tabular}

IPSS - International Prognostic Scoring System; DIPPS — Dynamic International Prognostic Scoring System

plus [11]. W ramach tego wskaźnika analizuje się trzy dodatkowe parametry: zapotrzebowanie na przetoczenia koncentratu krwinek czerwonych (kkcz), liczbę płytek krwi poniżej $100 \mathrm{G} / 1$, niekorzystny kariotyp (kariotyp złożony, $+8,-7 / 7 \mathrm{q}-$, i(17q), inv(3), -5/5q-, 12p- lub 11q23). Zgodnie $z$ DIPSS plus mediana przeżycia chorych $z$ grupy niskiego ryzyka ( $\mathrm{tj}$. nieobciążonych niekorzystnymi czynnikami prognostycznymi) wynosi około 15,4 roku, w grupie pośredniego ryzyka-1 (1 czynnik niekorzystny) - około 6,5 roku, w grupie pośredniego ryzyka-2 (2 lub 3 czynniki ryzyka) - około 2,9 roku, natomiast $\mathrm{w}$ grupie wysokiego ryzyka ( $\geq 4$ czynników niekorzystnych) — jedynie 1,3 roku. Zestawienie wskaźników prognostycznych IPSS, DIPSS, DIPSS plus przedstawiono w tabeli 1.
Pojawiają się badania wskazujące na znaczenie kliniczne nowych czynników prognostycznych w PMF — różnego rodzaju aberracji molekularnych, takich jak mutacje sprawcze (,phenotypic driver" mutation) oraz mutacje modyfikujące fenotyp choroby (,non phenotypic driver" mutation), w tym mutacje wysokiego ryzyka (HMR, high-molecular risk) [12-21].

\section{Nowe czynniki prognostyczne}

\section{Mutacje sprawcze - phenotypic driver}

Począwszy od 2005 roku, gdy trzy niezależne grupy badaczy [12-14] opisały obecność mutacji somatycznej V617F w obrębie egzonu 14. genu kinazy Janus 2 (JAK2, Janus kinase 2), zrozumienie 
etiopatogenezy MPN $\mathrm{Ph}(-)$ zmieniło się diametralnie. W kolejnych latach pojawiały się publikacje, w których analizowano wpływ obciążenia allelem zmutowanym $J A K 2 \mathrm{~V} 617 \mathrm{~F}$ na fenotyp oraz na rokowanie pacjentów $z \mathrm{MPN} \mathrm{Ph}(-)[15,16]$. Większe obciążenie allelem zmutowanym JAK2V617F wpływało na gorsze rokowanie w PV, natomiast u chorych $z$ mielofibrozą zaobserwowano odwrotną zależność - niższą przeżywalność u chorych z mniejszą ilością zmutowanego allelu JAK2 V617F [17]. W kolejnych latach w grupie MPN $\mathrm{Ph}(-)$ bez mutacji JAK2 $\mathrm{V} 617 \mathrm{~F}$ opisano inne mutacje, takie jak mutacja genu JAK2 w obrębie egzonu 12. [18], w obrębie genu kodującego receptor dla trombopoetyny MPL (MPL thrombopoietin receptor) [19] oraz w obrębie sekwencji genu kalretikuliny (CALR, calreticulin) [20]. Istnieje wiele podtypów mutacji $C A L R$, ale najczęstsze to typ 1 (delecja $52 \mathrm{bp}$ ) i typ 2 (insercja 5 bp). Tefferi i wsp. [21] wykazali, że rokowanie nosicieli mutacji $C A L R$ typ 1 jest lepsze niż rokowanie u chorych CALR typ 2 (typ $2 v$. typ 1 ; $\mathrm{p}=0,003$, współczynnik ryzyka [HR, hazard ratio] 2,5, 95-procentowy przedział ufności [CI, confidence interval], 1,9-3,7). Mutacje sprawcze najprawdopodobniej pojawiają się na wczesnym etapie patogenezy MPN Ph(-), odpowiadają za mieloproliferacje, nie leżą jednak u podłoża molekularnego choroby [22]. W przypadku PMF wyniki analizy częstości mutacji sprawczych są następujące: JAK2 V617F występuje u 50-60\% chorych, MPL W515/K u 5-10\%, CALR -u 20-30\%, a u 5-7\% chorych nie stwierdza się żadnej $z$ powyższych mutacji, czyli jest to tak zwana populacja potrójnie ujemna (TN, triple negative) [2,21]. Rumi i wsp. [23] zaobserwowali w grupie chorych $z$ mielofibrozą wpływ mutacji driver na przeżycie pacjentów. Szacowana mediana OS chorych z mutacją $C A L R$ to 17,7 roku, $\mathrm{z}$ mutacją $J A K 2 \mathrm{~V} 617 \mathrm{~F}$ - około 9,2 roku, natomiast i z mutacją $M P L-9,1$ roku. Najgorsze rokowanie zaobserwowano $\mathrm{w}$ grupie $\mathrm{TN} z$ medianą przeżycia około 3,2 roku [23, 24]. Wykazano, że wpływ rokowniczy mutacji driver jest niezależny od liczby punktów uzyskanych przez pacjentów w skalach IPSS i DIPPS [23].

\section{Mutacje non-phenotypic driver}

Wraz z postępem choroby dochodzi do ewolucji klonalnej z pojawieniem się kilku klonów komórek nowotworowych, przy czym dominującym klonem jest mutacja JAK2 V671F, CALR lub MPL. Dodatkowo wykazano, że w subpopulacjach komórkowych oprócz powyższych mutacji obserwowane są inne defekty molekularne, najczęściej o charakterze „mutacji modyfikujących fenotyp choroby” oraz odpowiedzialnych za transformacje choroby, bez wpływu na mieloproliferację [25-28].

U chorych $z$ mielofibrozą spośród mutacji non-phenotypic driver wyszczególniono pięć mutacji HMR - ASLX1 (additional sexcombs-like 1) stwierdzoną u około $21,7 \%$ chorych na PMF, SRSF2 (serine-arginine rich splicing factor 2) stwierdzoną u 8,5\%, EZH2 (enhancer of zeste homolog 2) stwierdzoną u 5,1\%,IDH (isocitrate dehydrogease) 1 i 2 stwierdzoną u 2,6\% [25-27]. Obecność tych mutacji powiązano $z$ krótszym OS oraz zwiększonym ryzykiem transformacji w AML u chorych na mielofibrozę [17, 25-28]. Guglielmelli i wsp. [29] dowiedli zmiennej częstości występowania mutacji HMR zależnie od typu mutacji driver; są one najczęstsze $\mathrm{w}$ grupie TN i najrzadsze w grupie $z$ mutacjami $C A L R$. Dodatkowo zauważono, że mutacje te występują częściej w grupach IPSS pośredniego-2 $\mathrm{i}$ wysokiego ryzyka, a liczba mutacji HMR jest odwrotnie skorelowana $z$ medianą OS $\mathrm{u}$ chorych na mielofibrozę, niezależnie od obecnie obowiązujących wskaźników prognostycznych. U chorych $z$ więcej niż 2 mutacjami HMR mediana OS wynosi 2,6 roku, z 1 mutacją HMR -7 lat, a bez mutacji HMR mediana OS wynosi 12,3 roku [27, 29]. Vanucchi i wsp. [30] wykazali, że występowanie mutacji HMR jest niezależnym od liczby punktów uzyskanych przez pacjentów w skalach IPSS i DIPPS plus czynnikiem prognostycznym dla OS (i transformacji do AML).

\section{Propozycje nowych wskaźników prognostycznych}

W miarę odkrywania nowych zaburzeń w MPN $\mathrm{Ph}(-)$ rozpoczęto prace nad badaniem ich wpływu na rokowanie pacjentów. Jak wyżej wspomniano, Rumi i wsp. [23] wykazali niezależny od IPSS czy DIPPS wpływ mutacji driver na OS chorych na PMF. Zaproponowany przez tę grupę model wskaźnika prognostycznego oparto na zmiennych wchodzących w skład wskaźnika IPSS oraz ocenie statusu mutacji driver. Chorzy zostali podzieleni na pięć grup rokowniczych: bardzo niskiego ryzyka (0 pkt.), niskiego ryzyka ( $1 \mathrm{pkt})$, pośredniego ryzyka (2-3 pkt.), wysokiego ryzyka (4-5 pkt.), bardzo wysokiego ryzyka (> 5 pkt.) (tab. 2). Analiza OS za pomocą modelu proporcjonalnego ryzyka Coxa wykazała, że HR w grupie niskiego ryzyka wynosi 4,2 (95\% CI, 1,4-12; $\mathrm{p}=0,007), \mathrm{w}$ grupie pośredniego ryzyka $-10,2$ (95\% CI, 3,6-28,6; $\mathrm{p}=0,001$ ), w grupie wysokiego ryzyka $-37,5(95 \% \mathrm{CI}, 13,3-105,8 ; \mathrm{p}=0,001)$, a w grupie bardzo wysokiego ryzyka $-88,6(95 \%$ CI, 30,3-259; $\mathrm{p}=0$,001) [23]. 
Tabela 2. Skala prognostyczna dla mielofibrozy (wg [23])

Table 2. Prognostic risk score in myelofibrosis (acc. to [23])

\begin{tabular}{|l|c|c|}
\hline Czynnik ryzyka & Punktacja wg Rumi i wsp. & Kategoria ryzyka \\
\hline Wiek $>65$ lat & 1 & 0 pkt. - bardzo niskie \\
1 pkt - niskie \\
\hline Objawy ogólne & 1 & $\begin{array}{c}2-3 \text { pkt. }- \text { pośrednie } \\
4-5 \text { pkt. }- \text { wysokie }\end{array}$ \\
\hline Stężenie hemoglobiny $<10 \mathrm{~g} / \mathrm{dl}$ & 1 & $>5$ pkt. - bardzo wysokie \\
\hline Liczba leukocytów $>25 \mathrm{G} / \mathrm{l}$ & 1 & \\
\hline Odsetek blastów we krwi obwodowej $\geq 1 \%$ & 1 & \\
\hline Obecność mutacji CALR & 1 & \\
\hline Obecność mutacji JAK2 V167F & 1 \\
\hline Obecność mutacji MPL & 1 \\
\hline TN & 1 & \\
\hline TN (triple negative) - tzw. populacja potrójnie ujemna &
\end{tabular}

Kolejne dwie propozycje modeli prognostycznych służą analizie nie tylko statusu mutacji driver, ale także mutacji HMR. Pierwsza propozycja to wskaźnik rokowniczy MIPPS (Mutation-Enhanced International Prognostic Scoring System) [30], w ramach którego bierze się pod uwagę następujące czynniki: wiek powyżej 60 lat (1,5 pkt.), obecność objawów ogólnych $(0,5$ pkt.), niedokrwistość poniżej $10 \mathrm{~g} / \mathrm{dl}(0,5$ pkt.), małopłytkowość poniżej $200 \mathrm{G} / 1$ (1 pkt.), status genetyczny: TN (1,5 pkt.), JAK2 (0,5 pkt.), MPL (0,5 pkt.) HMR (ASXL1, SRSF2) $(0,5$ pkt.). Chorych podzielono na cztery grupy: ryzyka wysokiego ( $\geq 4$ pkt.) z przewidywaną medianą OS 1,9 roku, HR 36,5 (19,4-68,9); pośredniego-2 (2-3,5 pkt.) z przewidywaną medianą OS 6,4 roku, HR 9,9 (5,5-17,7); pośredniego-1 (1-1,5 pkt). z przewidywanym średnim OS 9,7 roku, HR 4,7 (2,3-9,6); niskiego (0-0,5 pkt) z przewidywanym średnim OS 26,4 roku. Modyfikacją MIPPS jest skala GPSS (Genetic-Based Prognostic Scoring System), w ramach której analizuje się następujące zmienne: wiek chorego ( $\geq 60$ lat), wynik badania cytogenetycznego (wysokiego i bardzo wysokiego ryzyka), status genetyczny chorego, czyli obecność mutacji JAK2, MPL, CALR (typ 2), $A S X L 1$ i SRSF2 [31].

Omówione wyżej skale prognostyczne nie są obecnie obowiązującymi, wymagają weryfikacji w większej populacji chorych. Dodatkowo wydają się one zbyt skomplikowane do zastosowania w codziennej praktyce klinicznej (ocena zbyt wielu elementów), a w przypadku MIPSS i GPSS oznaczanie mutacji $A S X L 1$ i $S R S F 2 \mathrm{w}$ wielu ośrodkach obecnie nie jest możliwe.

Lepszą opcją wydaje się kolejna propozycja wskaźnika rokowniczego opracowana przez Rozovskiego i wsp. [32]. Podstawą tego modelu są trzy elementy: ocena pólilościowa obciążenia nieprawidłowym allelem JAK2 V617F (ang. JAK2 V617F allele burden; $<50 \% v$. $\geq 50 \%$ ), ocenie statusu TN (tak $v$. nie), wieku chorego (> 65. rż.v. $\leq 65$ rż.) (tab. 3). Do czynników złego rokowania zalicza się: JAK2 V617F allele burden poniżej 50\%, status TN, wiek powyżej 65. roku życia (tab. 2). Wskaźnik ten wymaga weryfikacji oraz porównania $z$ IPSS oraz DIPSS w dużej populacji pacjentów. Ważna jest również ocena przydatności wskaźnika rokowniczego przy kwalifikacji chorych do procedury przeszczepienia allogenicznych krwiotwórczych komórek macierzystych (allo-HSCT, allogeneic hematopoietic stem cell transplantation).

\section{Przeszczepienie allogenicznych krwiotwórczych komórek macierzystych a nowe wskaźniki prognostyczne}

Procedura allo-HSCT jest obarczona dużym ryzykiem - śmiertelność okołoprzeszczepowa (TRM, treatment-related mortality) wynosi 30-40\%, a przewidywany odsetek 3-letniego OS to 30-40\% $[33,34]$. Dlatego tak ważna jest prawidłowa kwalifikacja kandydatów do allo-HSCT. Zgodnie z zaleceniami ELN (European LeukemiaNet)/ /EBMT (European Group For Bone Marrow Transplantation) z 2015 roku allo-HSCT należy rozważyć u chorych poniżej 70 . roku życia, $z$ grupy ryzyka pośredniego-2 i wysokiego według IPSS/DIPSS oraz poniżej 65. roku życia w przypadku opornej na leczenie, zależnej od transfuzji niedokrwistości, obecności minimum $2 \%$ blatów we krwi obwodowej oraz w przypadku niekorzystnego kariotypu zdefiniowanego w skali DIPSS plus [35].

Tefferi i wsp. [36] w 2014 roku sugerowali zmianę zaleceń zgodnie ze statusem mutacji $A S X L 1$ oraz CALR. Według autorów chorych bez mutacji $A S X L 1$, nosicieli mutacji CALR (ASXL1-/ $/ C A L R+$ ) nie powinno się poddawać procedurze allo-HSCT — ci pacjenci są kandydatami do leczenia 
Tabela 3. Nowe propozycje skal prognostycznych dotyczących mielofibrozy: MIPPS (Mutation-Enhanced International Prognostic Scoring System), GPSS (Genetic-Based Prognostic Scoring System), skala wg Rozovskiego i wsp.: A. Czynniki ryzyka; B. Grupy ryzyka i mediana przeżycia

Table 3. New prognostic risk scores proposed for myelofibrosis: MIPPS (Mutation-Enhanced International Prognostic Scoring System), GPSS (Genetic-Based Prognostic Scoring System), score according to Rozovski et al.: A. Risk factors; B. Risk groups and median survival

A

\begin{tabular}{|c|c|c|c|}
\hline Czynnik ryzyka & & Punktacja & \\
\hline & MIPSS & GPSS & Rozovski i wsp. \\
\hline Wiek $>60$ lat & 1,5 & 2 & > 65 rż. \\
\hline Objawy ogólne & 0,5 & - & - \\
\hline Stężenie hemoglobiny $<10 \mathrm{~g} / \mathrm{dl}$ & 0,5 & - & \\
\hline Liczba płytek krwi < 200 G/l & 1 & 2 & - \\
\hline TN & 1,5 & 2 & - \\
\hline Obecność mutacji JAK2 V617F & 0,5 & 2 & Tak \\
\hline Obecność mutacji MPL & 0,5 & $A S X L 1-1 \mathrm{pkt}$ & $J A K 2<50 \% * * *$ \\
\hline Obecność mutacji HMR (ASXL1, SRSF2)* & 0,5 & $S R S F 2-1 \mathrm{pkt}$ & - \\
\hline $\begin{array}{l}\text { Cytogenetyka**: } \\
\text { - bardzo wysokie ryzyko } \\
\text { - wysokie ryzyko }\end{array}$ & & $\begin{array}{l}1 \\
1\end{array}$ & - \\
\hline Obecność mutacji CALR (typ 2) & & 2 & - \\
\hline
\end{tabular}

*Mutacje $E Z H 2, I D H 1 / 2$ - nie osiągnięto statystycznie znaczącego $p_{;}{ }^{* *}$ cytogenetyka ryzyko bardzo wysokie: monosomia, inv (3), i(17q), $-7 / 7 q-$, zaburzenia w $11 q$ lub 12 , ryzyko wysokie: kariotyp złożony, 2 zaburzenia niezaliczające się do cytogenetyki bardzo wysokiego ryzyka, $5 q-,+8$, inne trisomie poza +9 , inne zaburzenia cytogenetyczne niezaliczane do pozostałych grup ryzyka cytogenetycznego, ryzyko pośrednie: izolowane $20 q-1,1 q+$ lub inne izolowane zaburzenia cytogenetyczne, -Y lub inne zaburzenia cytogenetyczne $w$ chromosomach $Y$ lub X, ryzyko niskie: kariotyp normalny, izolowane $13 q-$ lub +9 ; *** obciążenie nieprawidłowym allelem JAK2 V617F (allelic burden)

B

\begin{tabular}{|c|c|c|}
\hline Liczba punktów & Kategoria ryzyka & Mediana przeżycia (lata) \\
\hline \multicolumn{3}{|l|}{ MIPSS } \\
\hline $0-0,5$ & Niskie & 26,4 \\
\hline $1-1,5$ & Pośrednie-1 & 9,7 (HR 4,7; 95\% Cl, 2,3-9,6) \\
\hline $2-3,5$ & Pośrednie-2 & $6,4(\mathrm{HR} 9,9 ; 95 \% \mathrm{Cl}, 5,5-17,7)$ \\
\hline$\geq 4$ & Wysokie & 1,9 (HR 36,5; 95\% Cl, 19,4-68,9) \\
\hline \multicolumn{3}{|l|}{ GPSS } \\
\hline 0 & Niskie & Nieosiągnięta \\
\hline $1-2$ & Pośrednie-1 & $>17,9(\mathrm{HR} \mathrm{4,7;} 95 \% \mathrm{Cl}, 1,7-13,0)$ \\
\hline $3-4$ & Pośrednie-2 & 5 (HR 10,7; 95\% Cl, 3,9-29,3) \\
\hline $5-6$ & Wysokie & $2,2(\mathrm{HR} 29,2 ; 95 \% \mathrm{Cl}, 10,6-80,0)$ \\
\hline \multicolumn{3}{|l|}{ Rozovski i wsp. } \\
\hline 0 & Niskie & 10,5 \\
\hline 1 & Pośrednie & 6 \\
\hline 2 & Wysokie & 2,9 \\
\hline
\end{tabular}

HR (hazard ratio) — współczynnik ryzyka; Cl (confidence interval) — przedział ufności

w ramach badań klinicznych. Natomiast u chorych z DIPPS niskim i pośrednim-1, nosicieli mutacji $A S X L 1$, bez mutacji $C A L R(A S X L 1+/ C A L R-)$ allo-HSCT powinno się rozważyć (tab. 4) [36]. Obecnie, zgodnie $z$ zaleceniami ELN/EBMT z 2015 roku, stratyfikacja według markerów molekularnych wymaga dalszej obserwacji klinicznej. Sugeruje się jednak rozważenie allo-HSCT w grupie TN (JAK2-/
/CALR-/MPL-) ryzyka pośredniego-1 według IPSS/ /DIPSS i/lub z obecnością mutacji ASXL1 [35].

\section{Nowe wskaźniki prognostyczne w erze nowych leków}

Leki dotychczas stosowane w terapii PMF wykazująjedynie działanie objawowe i nie wpływają 
Tabela 4. Propozycja postępowania u chorych na pierwotną mielofibrozę zgodnie ze statusem mutacji ASXL1 i CALR (źródło [36])

Table 4. Proposed management of primary myelofibrosis patients according to CALR/ASXL1 mutation status (source [36])

\begin{tabular}{|c|c|c|c|}
\hline \multirow[t]{2}{*}{ Ryzyko wg DIPPS plus } & \multicolumn{3}{|c|}{ Ryzyko molekularne } \\
\hline & CALR-IASXL1+ & $C A L R+/ A S X L 1+C A L R-/ A S X L 1-$ & $C A L R+/ A S X L 1-$ \\
\hline Wysokie & $\begin{array}{c}\text { allo-HSCT } \\
\text { lub } \\
\text { badania kliniczne }\end{array}$ & allo-HSCT & allo-HSCT \\
\hline Pośrednie-2 & $\begin{array}{c}\text { allo-HSCT } \\
\text { lub } \\
\text { badania kliniczne }\end{array}$ & $\begin{array}{c}\text { allo-HSCT } \\
\text { lub } \\
\text { badania kliniczne }\end{array}$ & Badania kliniczne \\
\hline Pośrednie-1 & $\begin{array}{c}\text { allo-HSCT } \\
\text { lub } \\
\text { badania kliniczne }\end{array}$ & $\begin{array}{c}\text { Obserwacja } \\
\text { lub } \\
\text { badania kliniczne }\end{array}$ & Obserwacja \\
\hline Niskie & $\begin{array}{c}\text { allo-HSCT } \\
\text { lub } \\
\text { badania kliniczne }\end{array}$ & Obserwacja & Obserwacja \\
\hline
\end{tabular}

na przeżycie chorych. U pacjentów $z$ IPSS niskiego ryzyka nie powinno się podejmować farmakoterapii, zaś u pacjentów z IPSS ryzyka pośredniego-1 leczenie powinno być ukierunkowane na łagodzenie objawów klinicznych. Zgodnie $z$ obowiązującymi obecnie zaleceniami młodzi chorzy $z$ IPSS pośrednim-2 i wysokim powinni być kwalifikowani do allo-HSCT. Jest to nadal jedyna opcja dająca szansę wyleczenia PMF. Procedura ta jednak wiąże się $z$ dużym ryzykiem powikłań [33, 34].

Lepsze poznanie patogenezy MPN $\mathrm{Ph}(-) /$ /mielofibrozy umożliwiło opracowanie nowych leków [37-40]. W 2011 roku uzyskano rejestrację jedynego (obecnie) inhibitora kinazy tyrozynowej $J A K 1 / J A K 2$ dla chorych na mielofibrozę, $z$ objawową splenomegalią i/lub objawami ogólnymi. Rejestracja ta była możliwa dzięki dwóm randomizowanym badaniom COMFORT-I (ruksolitynib $v$. placebo) i COMFORT-II (ruksolitynib $v$. najlepsza dostępna terapia). Lek ten pozwala na znaczne ograniczenie splenomegalii - 35-procentową redukcję rozmiarów śledziony w tygodniu 24. (COMFORT-1: $41,9 \%$ v. $0,7 \%$ ) i tygodniu 48. (COMFORT-2: $28,5 \%$ v. $0 \%$ ). Dodatkowo obserwowano poprawę w zakresie objawów ogólnych. W badaniu COMFORT-1 po 24 tygodniach odsetek chorych $z$ co najmniej 50-procentową poprawą objawów ogólnych wynosił $45,9 \%$ u chorych leczonych ruksolitynibem i 5,3\% wśród chorych otrzymujących placebo. Uzyskana poprawa nie zależała od statusu mutacji JAK2. Dodatkowo w badaniu COMFORT-1 wykazano korzyść w odniesieniu do OS wśród chorych leczonych ruksolitynibem. Przy medianie obserwacji wynoszącej 51 tygodni zanotowano 13 $(8,4 \%)$ zgonów w grupie otrzymującej ruksolitynib i $24(15,7 \%)$ zgony w grupie przyjmującej placebo. Uważa się, że ruksolitynib ma raczej działanie antycytokinowe niż antyproliferacyjne. Lek ten nie redukuje w znaczący sposób ilości allelu zmutowanego JAK2, obecnie brakuje też danych na temat zahamowania włóknienia szpiku [37, 38]. Trwają badania nad nowymi inhibitorami JAK2 (pakritinib i momelotinib), innymi inhibitorami $J A K$ oraz lekami o innym mechanizmie działania, takimi jak: inhibitory deacetylazy histonowej (np. panobinostat - u niektórych pacjentów oprócz zmniejszenia rozmiarów śledziony powoduje regresję włóknienia w szpiku kostnym), inhibitory angiogenezy (bewacyzumab), inhibitory mTOR (mammalian target of rapamycin) (ewerolimus - w badaniach fazy $1 / 2$ uzyskano $60 \%$ odpowiedzi klinicznych) czy leki hipometylujące [39, 40]. W związku ze złożonym patomechanizmem genetycznym MPN $\mathrm{Ph}(-)$, a zwłaszcza PMF, większą szansę na ich skuteczność stwarzają terapie złożone [33, 34, 39-41].

\section{Podsumowanie}

Ostatnie lata umożliwiły lepsze poznanie patogenezy MPN $\mathrm{Ph}(-)$. W miarę odkrywania nowych zaburzeń genetycznych starano się weryfikować ich znaczenie prognostyczne, zwłaszcza w mielofibrozie. Nowo powstałe propozycje skal prognostycznych (MIPSS, GPSS, model wg Rumi i wsp. oraz wg Rozovskiego i wsp., a także model modyfikujący kwalifikację do allo-HSCT oparty na ocenie $A S X L 1 / C A L R$ ) nie są jeszcze standardami postępowania, wymagają weryfikacji w większej populacji chorych oraz porównania ich $z$ obecnie obowiązującymi modelami prognostycznymi, takimi jak 
IPSS i DIPSS/DIPPS plus. Obecnie najprostszym do zastosowania w codziennej praktyce klinicznej wydaje się model proponowany przez Rozovskiego i wsp., nie uwzględnia on jednak mutacji $A S X L 1$ i innych mutacji HMR.

Rokowanie w mielofibrozie jest bardzo złe, a jedyną opcją terapeutyczną umożliwiającą wyleczenie pozostaje allo-HSCT. Procedura ta jest jednak obarczona dużą toksycznością. Być może dzięki nowym wskaźnikom prognostycznym uda się w lepszy sposób wyodrębnić grupę chorych, $\mathrm{u}$ których procedura ta będzie niezbędna, oraz tych, u których zabieg ten mógłby być odroczony. Pojawiające się w badaniach klinicznych nowe leki, zwłaszcza stosowane we wstępnej fazie choroby i w terapii złożonej, stwarzają szansę na poprawę rokowania u chorych na PMF.

\section{Piśmiennictwo}

1. Alvarez-Larrán A, Ancochea A, García M, et al. WHO-histological criteria for myeloproliferative neoplasms: reproducibility, diagnostic accuracy and correlation with gene mutations and clinical outcomes. Br J Haematol. 2014; 166(6): 911-919, doi: 10.1111/ /bjh.12990, indexed in Pubmed: 24957246.

2. Barbui T, Thiele J, Gisslinger $\mathrm{H}$, et al. The 2016 revision of WHO classification of myeloproliferative neoplasms: Clinical and molecular advances. Blood Rev. 2016; 30(6): 453-459, doi: 10.1016/j. blre.2016.06.001, indexed in Pubmed: 27341755.

3. Barbui T, Thiele J, Vannucchi AM, et al. Problems and pitfalls regarding WHO-defined diagnosis of early/prefibrotic primary myelofibrosis versus essential thrombocythemia. Leukemia. 2013; 27(10): 1953-1958, doi: 10.1038/leu.2013.74, indexed in Pubmed: 23467025.

4. Ejerblad E, Kvasnicka HM, Thiele J, et al. Diagnosis according to World Health Organization determines the long-term prognosis in patients with myeloproliferative neoplasms treated with anagrelide: results of a prospective long-term follow-up. Hematology. 2013; 18(1): 8-13, doi: 10.1179/1607845412Y.0000000023, indexed in Pubmed: 22990042.

5. Cervantes F, Dupriez B, Pereira A, et al. New prognostic scoring system for primary myelofibrosis based on a study of the International Working Group for Myelofibrosis Research and Treatment. Blood. 2009; 113(13): 2895-2901, doi: 10.1182/ /blood-2008-07-170449, indexed in Pubmed: 18988864.

6. Dupriez B, Morel P, Demory JL, et al. Prognostic factors in agnogenic myeloid metaplasia: a report on 195 cases with a new scoring system. Blood. 1996; 88(3): 1013-1018, indexed in Pubmed: 8704209.

7. Cervantes F, Dupriez B, Pereira A, et al. New prognostic scoring system for primary myelofibrosis based on a study of the International Working Group for Myelofibrosis Research and Treatment. Blood. 2009; 113(13): 2895-2901, doi: 10.1182/ /blood-2008-07-170449, indexed in Pubmed: 18988864.

8. Passamonti F, Cervantes F, Vannucchi AM, et al. A dynamic prognostic model to predict survival in primary myelofibrosis: a study by the IWG-MRT (International Working Group for Myeloproliferative Neoplasms Research and Treatment). Blood. 2010; 115(9): 1703-1708, doi: 10.1182/blood-2009-09-245837, indexed in Pubmed: 20008785.
9. Tam CS, Abruzzo LV, Lin KI, et al. The role of cytogenetic abnormalities as a prognostic marker in primary myelofibrosis: applicability at the time of diagnosis and later during disease course. Blood. 2009; 113(18): 4171-4178, doi: 10.1182/ /blood-2008-09-178541, indexed in Pubmed: 19131547.

10. Hussein K, Pardanani AD, Van Dyke DL, et al. International Prognostic Scoring System-independent cytogenetic risk categorization in primary myelofibrosis. Blood. 2010; 115(3): 496-499, doi: 10.1182/blood-2009-08-240135, indexed in Pubmed: 19901264.

11. Gangat N, Caramazza D, Vaidya R, et al. DIPSS plus: a refined Dynamic International Prognostic Scoring System for primary myelofibrosis that incorporates prognostic information from karyotype, platelet count, and transfusion status. J Clin Oncol. 2011; 29(4): 392-397, doi: 10.1200/JCO.2010.32.2446, indexed in Pubmed: 21149668.

12. Kralovics R, Passamonti F, Buser AS, et al. A gain-of-function mutation of JAK2 in myeloproliferative disorders. N Engl J Med. 2005; 352(17): 1779-1790, doi: 10.1056/NEJMoa051113, indexed in Pubmed: 15858187.

13. Baxter EJ, Scott LM, Campbell PJ, et al. Cancer Genome Project. Acquired mutation of the tyrosine kinase JAK2 in human myeloproliferative disorders. Lancet. 2005; 365(9464): 1054 -1061, doi: 10.1016/S0140-6736(05)71142-9, indexed in Pubmed: 15781101.

14. James C, Ugo V, Le Couédic JP, et al. A unique clonal JAK2 mutation leading to constitutive signalling causes polycythaemia vera. Nature. 2005; 434(7037): 1144-1148, doi: 10.1038/nature03546, indexed in Pubmed: 15793561.

15. Vannucchi AM, Pieri L, Guglielmelli P. JAK2 allele burden in the myeloproliferative neoplasms: effects on phenotype, prognosis and change with treatment. Ther Adv Hematol. 2011; 2(1): 21-32, doi: 10.1177/2040620710394474, indexed in Pubmed: 23556073.

16. Tiedt R, Hao-Shen H, Sobas MA, et al. Ratio of mutant JAK2-V617F to wild-type Jak2 determines the MPD phenotypes in transgenic mice. Blood. 2008; 111(8): 3931-3940, doi: 10.1182/ /blood-2007-08-107748, indexed in Pubmed: 18160670.

17. Vannucchi AM, Lasho TL, Guglielmelli P, et al. Mutations and prognosis in primary myelofibrosis. Leukemia. 2013; 27(9): 1861-1869, doi: 10.1038/leu.2013.119, indexed in Pubmed: 23619563.

18. Martínez-Avilés L, Besses C, Alvarez-Larrán A, et al. JAK2 exon 12 mutations in polycythemia vera or idiopathic erythrocytosis. Haematologica. 2007; 92(12): 1717-1718, doi: 10.3324/haematol.12011, indexed in Pubmed: 18056003.

19. Chaligné R, Tonetti $C$, Besancenot R, et al. New mutations of MPL in primitive myelofibrosis: only the MPL W515 mutations promote a G1/S-phase transition. Leukemia. 2008; 22(8): 1557-1566, doi: 10.1038/leu.2008.137, indexed in Pubmed: 18528423.

20. Klampfl T, Gisslinger H, Harutyunyan AS, et al. Somatic mutations of calreticulin in myeloproliferative neoplasms. N Engl J Med. 2013; 369(25): 2379-2390, doi: 10.1056/NEJMoa1311347, indexed in Pubmed: 24325356.

21. Tefferi A, Lasho TL, Tischer A, et al. The prognostic advantage of calreticulin mutations in myelofibrosis might be confined to type 1 or type 1-like CALR variants. Blood. 2014; 124(15): 2465-2466, doi: 10.1182/blood-2014-07-588426, indexed in Pubmed: 25301336.

22. Shammo JM, Stein BL. Mutations in MPNs: prognostic implications, window to biology, and impact on treatment decisions. Hematology Am Soc Hematol Educ Program. 2016; 2016(1): 552-560, doi: 10.1182/asheducation-2016.1.552, indexed in Pubmed: 27913528. 
23. Rumi E, Pietra D, Pascutto C, et al. Associazione Italiana per la Ricerca sul Cancro Gruppo Italiano Malattie Mieloproliferative Investigators. Clinical effect of driver mutations of JAK2, CALR, or MPL in primary myelofibrosis. Blood. 2014; 124(7): 1062-1069, doi: 10.1182/blood-2014-05-578435, indexed in Pubmed: 24986690 .

24. Tefferi A, Lasho TL, Finke CM, et al. CALR vs JAK2 vs MPL-mutated or triple-negative myelofibrosis: clinical, cytogenetic and molecular comparisons. Leukemia. 2014; 28(7): 1472-1477, doi: 10.1038/leu.2014.3, indexed in Pubmed: 24402162.

25. Skoda RC, Duek A, Grisouard J. Pathogenesis of myeloproliferative neoplasms. Exp Hematol. 2015; 43(8): 599-608, doi: 10.1016/j. exphem.2015.06.007, indexed in Pubmed: 26209551.

26. Lundberg P, Karow A, Nienhold R, et al. Clonal evolution and clinical correlates of somatic mutations in myeloproliferative neoplasms. Blood. 2014; 123(14): 2220-2228, doi: 10.1182/ /blood-2013-11-537167, indexed in Pubmed: 24478400.

27. Tefferi A. Novel mutations and their functional and clinical relevance in myeloproliferative neoplasms: JAK2, MPL, TET2, ASXL1, CBL, IDH and IKZF1. Leukemia. 2010; 24(6): 1128-1138, doi: 10.1038/leu.2010.69, indexed in Pubmed: 20428194.

28. Schaub FX, Looser R, Li S, et al. Clonal analysis of TET2 and JAK2 mutations suggests that TET2 can be a late event in the progression of myeloproliferative neoplasms. Blood. 2010; 115(10): 2003-2007, doi: 10.1182/blood-2009-09-245381, indexed in Pubmed: 20061559.

29. Guglielmelli P, Lasho TL, Rotunno G, et al. The number of prognostically detrimental mutations and prognosis in primary myelofibrosis: an international study of 797 patients. Leukemia. 2014; 28(9): 1804-1810, doi: 10.1038/leu.2014.76, indexed in Pubmed: 24549259 .

30. Vannucchi AM, Guglielmelli P, Rotunno G, et al. Mutation-Enhanced International Prognostic Scoring System (MIPSS) for primary myelofibrosis: an AGIMM \& IWG-MRT Project. Blood. 2014; 124: 405.

31. Tefferi A, Guglielmelli P, Finke C, et al. Integration of mutations and karyotype towards a genetics-based prognostic scoring system (GPSS) for primary myelofibrosis. Blood. 2014; 124: 406.

32. Rozovski U, Verstovsek S, Manshouri T, et al. An accurate, simple prognostic model consisting of age, JAK2, CALR, and MPL mutation status for patients with primary myelofibrosis. Haematologica. 2017; 102(1): 79-84, doi: 10.3324/haematol.2016.149765, indexed in Pubmed: 27686378.
33. Tefferi A, Vainchenker W. Myeloproliferative neoplasms: molecular pathophysiology, essential clinical understanding, and treatment strategies. J Clin Oncol. 2011; 29(5): 573-582, doi: 10.1200/ /JC0.2010.29.8711, indexed in Pubmed: 21220604.

34. Tefferi A. How I treat myelofibrosis. Blood. 2011; 117(13): 3494-3504, doi: 10.1182/blood-2010-11-315614, indexed in Pubmed: 21200024 .

35. Kröger NM, Deeg JH, Olavarria E, et al. Indication and management of allogeneic stem cell transplantation in primary myelofibrosis: a consensus process by an EBMT/ELN international working group. Leukemia. 2015; 29(11): 2126-2133, doi: 10.1038/ /leu.2015.233, indexed in Pubmed: 26293647.

36. Tefferi A, Guglielmelli P, Lasho TL, et al. CALR and ASXL1 mutations-based molecular prognostication in primary myelofibrosis: an international study of 570 patients. Leukemia. 2014; 28(7): 1494-1500, doi: 10.1038/leu.2014.57, indexed in Pubmed: 24496303 .

37. Verstovsek S, Mesa RA, Gotlib J, et al. A double-blind, placebo-controlled trial of ruxolitinib for myelofibrosis. N Engl J Med. 2012; 366(9): 799-807, doi: 10.1056/NEJMoa1110557, indexed in Pubmed: 22375971.

38. Harrison C, Kiladjian JJ, Al-Ali HK, et al. JAK inhibition with ruxolitinib versus best available therapy for myelofibrosis. $\mathrm{N}$ Engl J Med. 2012; 366(9): 787-798, doi: 10.1056/NEJMoa1110556, indexed in Pubmed: 22375970.

39. Guglielmelli P, Barosi G, Rambaldi A, et al. AIRC-Gruppo Italiano Malattie Mieloproliferative (AGIMM) investigators. Safety and efficacy of everolimus, a mTOR inhibitor, as single agent in a phase 1/2 study in patients with myelofibrosis. Blood. 2011; 118(8): 2069-2076, doi: 10.1182/blood-2011-01-330563, indexed in Pubmed: 21725052

40. Stahl M, Zeidan AM. Management of myelofibrosis: JAK inhibition and beyond. Expert Rev Hematol. 2017; 10(5): 459-477, doi: 10.1080/17474086.2017.1317590, indexed in Pubmed: 28395559.

41. Tefferi A, Barosi G, Mesa RA, et al. IWG for Myelofibrosis Research and Treatment (IWG-MRT). International Working Group (IWG) consensus criteria for treatment response in myelofibrosis with myeloid metaplasia, for the IWG for Myelofibrosis Research and Treatment (IWG-MRT). Blood. 2006; 108(5): 1497-1503, doi: 10.1182/blood-2006-03-009746, indexed in Pubmed: 16675707. 